\title{
Darier's disease: Clinical and demographic features of nine cases
}

\section{Darier hastalığ: Dokuz olgunun klinik ve demografik özellikleri}

๑ Sevil Savaș, ๑ Ayșe Esra Koku Aksu, ๑ Ebru Sarıkaya, ๑ Cem Leblebici* , Mehmet Salih Gürel

İstanbul Training and Research Hospital, Clinic of Dermatology, ${ }^{*}$ Clinic of Pathology, İstanbul, Turkey

\begin{abstract}
Background and Design: Darier's disease is a genetic disorder of keratinization with autosomal dominant inheritance. In the article presented here, demographical, clinical and histopathological findings and treatment outcome of Darier's disease are discussed with 9 cases. Materials and Methods: We performed a retrospective study of all the patients diagnosed with Darier's disease at the Department of Dermatology of Istanbul Training and Research Hospital, between 2008 and 2016.

Results: During the observation period, we identified 9 patients with Darier's disease; 6 males and 3 females with a mean age of 32.5 years. Two cases were from the same family (mother and child) and no family history was found in the other seven patients. Skin lesions in the form of keratotic papules were noted in seborrhoeic areas, essentially the head-neck and trunk. Four patients had hand involvement, five patients had nail lesions. Conclusion: Darier's disease is a rare genodermatosis and should be considered in the differential diagnosis of dermatoses with keratotic papular lesions.
\end{abstract}

Keywords: Darier's disease, genodermatosis, acantholytic dyskeratosis

Öz

Amaç: Darier hastalığı otozomal dominant geçişli bir genetik keratinizasyon bozukluğudur. Bu makalede, 9 olguda hastalığın demografik, klinik ve histopatolojik muayene bulgularının ve tedavi sonuçlarının tartışıması hedeflenmiştir.

Gereç ve Yöntem: İstanbul Eğitim ve Araştırma Hastanesi, Dermatoloji Kliniği'nde 2008-2016 yılları arasında Darier hastalığı tanısı alan olgular retrospektif olarak değerlendirildi.

Bulgular: Çalışma periyodunda 9 hasta Darier hastalığı tanısı aldı; hastaların 6'sı erkek 3'ü kadın olup yaş ortalaması 32,5 idi. iki olgu aynı ailedendi (anne ve çocuk), diğer yedi olguda ise soygeçmişte Darier hastalığı saptanmadı. Hastalarımızda seboreik alan yerleşimli özellikle baş-boyun ve gövdeyi tutan keratotik papüller mevcuttu. Dört hastada el tutulumu, beş hastada tırnak lezyonları mevcuttu. Sonuç: Darier hastalı̆̆ı nadir görülen bir genodermatoz olup keratotik papüler lezyonlarla seyreden dermatozların ayırııı tanısında akla gelmelidir.

Anahtar Kelimeler: Darier hastalığı, genodermatoz, akantolitik diskeratoz

\section{Introduction}

Darier's disease is an autosomal dominant inherited genodermatosis characterized by abnormal keratinization of the skin, genodermatosis and involvement of the nails and mucous membrane, however, it is not always familial'. It mostly develops in the first two decades of life, but the onset can also be at a later age $\mathrm{e}^{2,3}$. The 10-year incidence of new cases is estimated to be $4 /$ million $^{4}$.

Darier's disease can be seen in either generalized autosomal dominant or localized/segmental post-zygotic form. Diagnosis is based on the typical clinical appearance and histological findings revealing acantholytic dyskeratosis. The characteristic clinical manifestation of the disease is squamous

Address for Correspondence/Yazışma Adresi: Sevil Savaş MD, İstanbul Training and Research Hospital, Clinic of Dermatology, İstanbul, Turkey Phone: +90 5542616854 E-mail: seaevil_87@hotmail.com Received/Geliş Tarihi: 22.01.2017 Accepted/Kabul Tarihi: 12.12.2017

ORCID ID: orcid.org/0000-0002-4392-4671 
hyperkeratotic yellow-brown papules and plaques over seborrheic and flexible areas of the body ${ }^{5}$.

\section{Materials and Methods}

In this study, patients diagnosed with Darier's disease in our dermatology outpatient clinic between 2008 and 2016 were retrospectively evaluated. All patients gave written consents. The diagnosis was confirmed by clinical features or histopathological findings. The patients' demographic and clinical data, such as age, gender, age of onset of symptoms, family history, and treatment responses were obtained from their medical records.

\section{Statistical Analysis}

SPSS v.21.0 program was used for statistical evaluation of the obtained data. Continuous data were expressed as mean, standard deviation, while categorical data were expressed as number and percentage.

\section{Results}

The case series comprised nine patients ( 6 male and 3 female) aged between 11 and 67 years (mean age: 32.5 years). The age of onset of the disease ranged from 8 to 47 years with a mean of 19.7. Two patients were from the same family (mother and child), whereas the remaining 7 cases did not have a family history of Darier's disease. In Darier's disease, cutaneous lesions are initially observed over

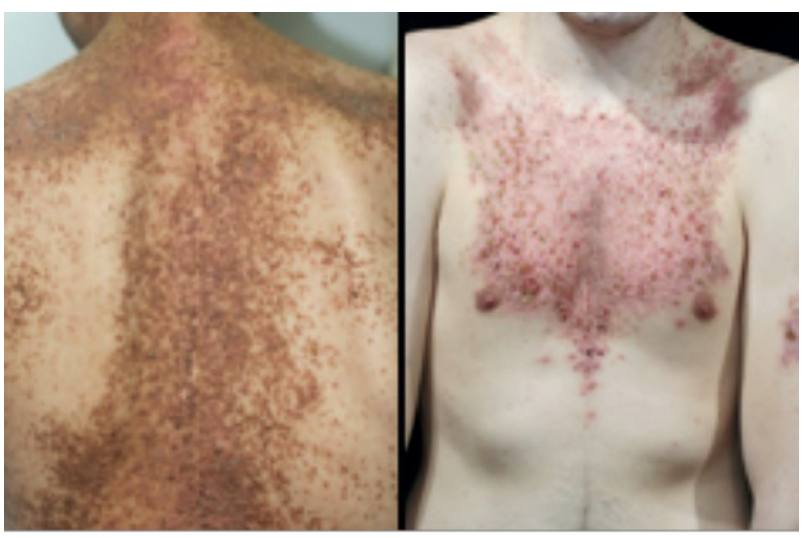

Figure 1. Keratotic papules, erythematous papules and brown crusted papules over seborrhoeic areas

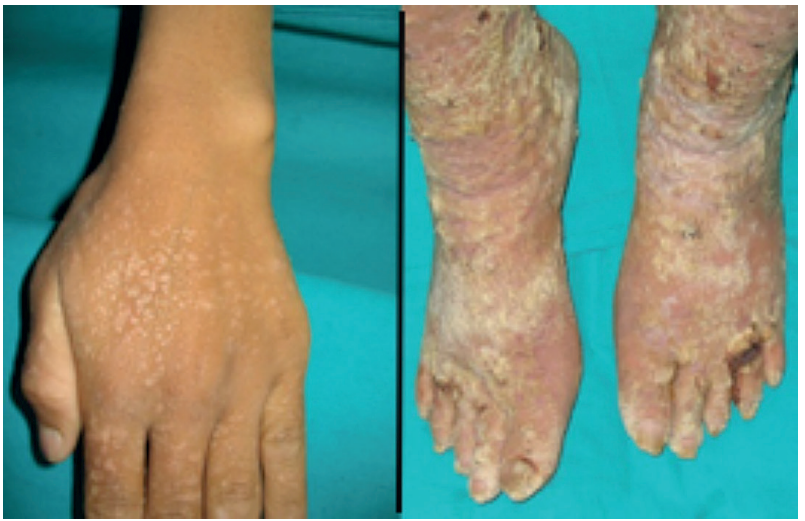

Figure 2. Acrokeratosis verruciformis-like lesions on the back of the hand and hyperkeratosis on the dorsum of the feet seborrheic areas. In patients in the current study, the head and neck, trunk, extremities, and flexural areas were affected (Figure 1). Hand involvement is common, and it was present in 4 patients in this series, of whom 3 had acrokeratosis verruciformis-like lesions on the back of the hand and 1 had palmoplantar keratoderma (Figure 2). In addition, we observed keratotic erythematous brown crusted verrucous papules and hypertrophic plaques. In one of the patients, more than $80 \%$ of the body was involved, and the disease manifestation was severe with verrucous plaques, intense desquamation and fissures in the face and extremities (Figure 3). One of the patients had a predominantly flexural involvement and minimal involvement in other areas (Figure 4). In one case, there were keratotic papules in a linear fashion following the lines of Blaschko (Figure 5) (Table 1). In all cases, the symptoms flared up during the summer months, under hot and humid conditions, and after mechanical trauma. Seven patients complained of itching.

Nail involvement was present in 5 patients with the following signs: longitudinal red-white lines (4 patients), subungual hyperkeratosis (2 patients), V-shaped splitting (4 patients), and distal notches (4 patients) (Figure 6). One patient was observed to have plaques on the buccal mucosa formed by the coalescence of papillary lesions and papules. Histopathological examination of all the patients revealed a group of dyskeratotic cells with an elongated nucleus in the suprabasal cleft and epidermis. These cells were either corps ronds with a basophilic nucleus surrounded by a clear halo or grains with a pyknotic nucleus in the stratum corneum (Figure 7).

Mental retardation was seen in 1 patient. Topical retinoid and steroid therapy was initiated in 4 patients, and their symptoms were reduced,

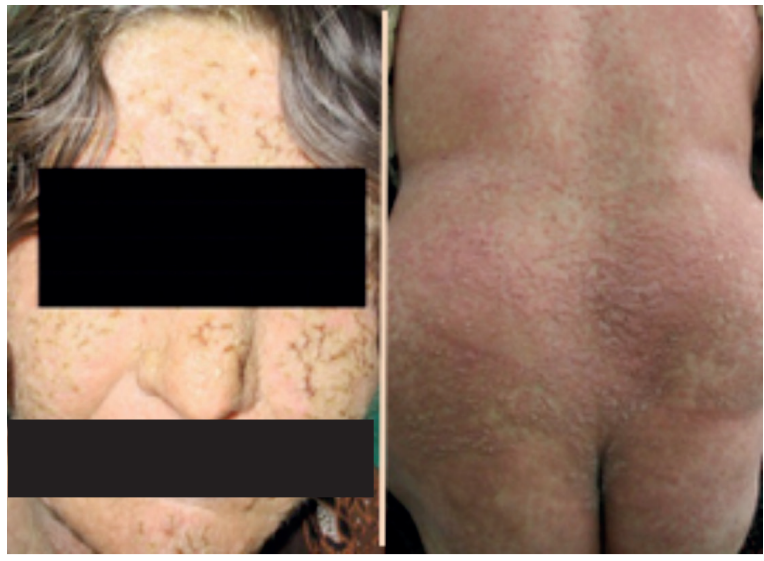

Figure 3. Common verrucous papules and plaques on the face and body, intense desquamation and fissures

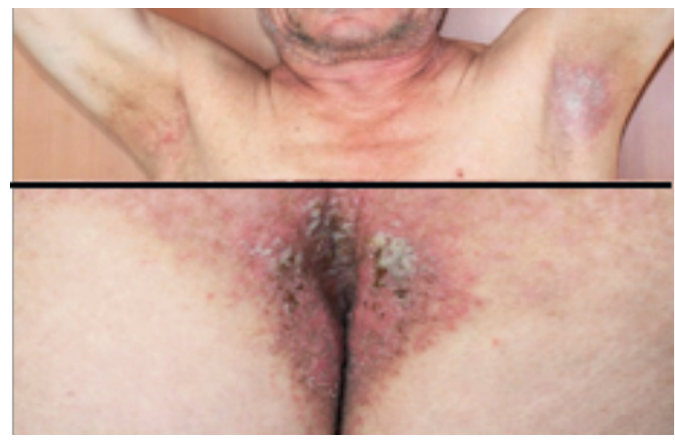

Figure 4. Squamous and brown crusted papules on axillary and intergluteal sulcus 


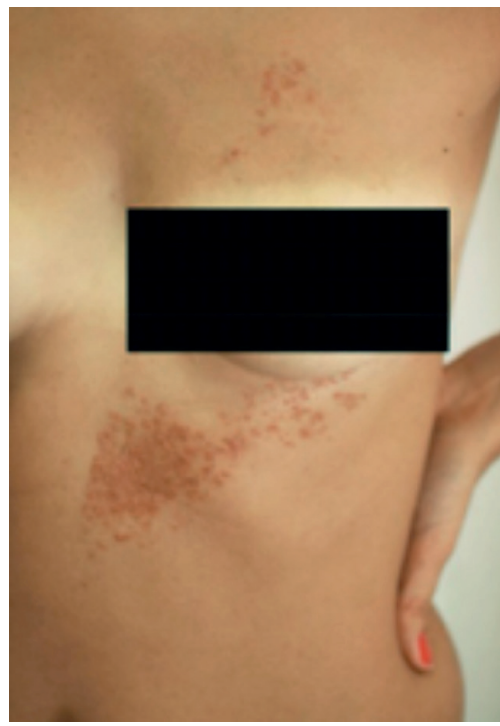

Figure 5. Pink millimetric papules with a fine scale starting from above and under the left breast (middle line), and extending to the back however, recurrence occurred with the termination of the treatment. Five patients with severe and diffuse Darier's disease were started on acitretin treatment, and there was a good response to treatment in $80 \%$ of these patients.

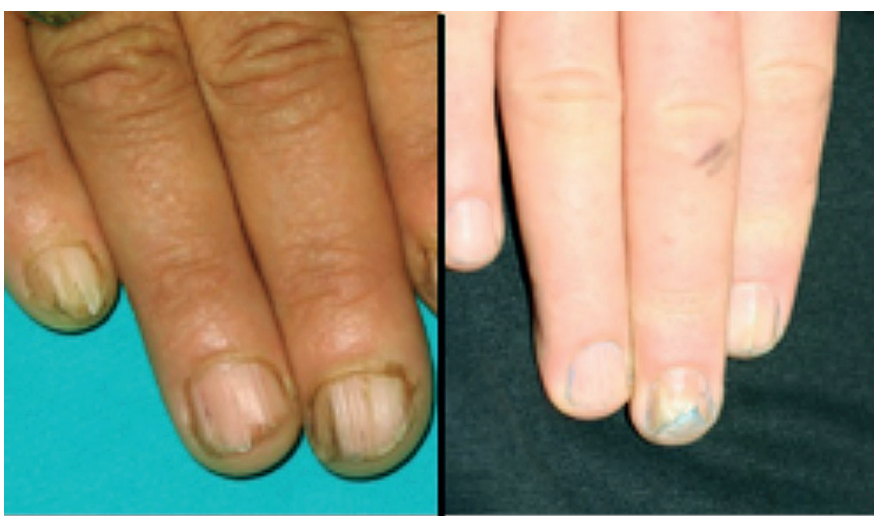

Figure 6. Longitudinal red-white lines in the nails and V-shaped notches and fissures in the distal of the nail

\section{Table 1. Clinical features of the cases}

\begin{tabular}{|c|c|c|c|c|c|c|c|c|c|}
\hline Patient number & 1 & 2 & 3 & 4 & 5 & 6 & 7 & 8 & 9 \\
\hline Age/gender & $30 / F$ & $32 / M$ & $67 / M$ & $30 / \mathrm{M}$ & $19 / \mathrm{M}$ & $44 / F$ & 29/F & $11 / M$ & $31 / M$ \\
\hline \multicolumn{10}{|l|}{ Involvement } \\
\hline Body & $\sqrt{ }$ & $\sqrt{ }$ & & $\sqrt{ }$ & $\sqrt{ }$ & $\sqrt{ }$ & & & $\sqrt{ }$ \\
\hline Extremities & & & & $\sqrt{ }$ & $\sqrt{ }$ & $\sqrt{ }$ & $\sqrt{ }$ & $\sqrt{ }$ & \\
\hline Hand & & $\sqrt{ }$ & & & & $\sqrt{ }$ & $\sqrt{ }$ & $\sqrt{ }$ & \\
\hline Segmental & $\sqrt{ }$ & & & & & & & & \\
\hline \multicolumn{10}{|l|}{ Clinical features } \\
\hline Keratotic papules & & $\sqrt{ }$ & $\sqrt{ }$ & $\sqrt{ }$ & $\sqrt{ }$ & $\sqrt{ }$ & $\sqrt{ }$ & $\sqrt{ }$ & $\sqrt{ }$ \\
\hline Erythematous papules & $\sqrt{ }$ & $\sqrt{ }$ & $\sqrt{ }$ & & $\sqrt{ }$ & $\sqrt{ }$ & $\sqrt{ }$ & $\sqrt{ }$ & $\sqrt{ }$ \\
\hline
\end{tabular}

\section{Table 2. An overview of the patient characteristics reported in the literature and in this study}

\begin{tabular}{|l|l|l|l|l|l|l|l|l|l|}
\hline Sources & $\begin{array}{l}\text { Study } \\
\text { period }\end{array}$ & $\begin{array}{l}\text { Number } \\
\text { of cases }\end{array}$ & $\begin{array}{l}\text { Age } \\
\text { range }\end{array}$ & $\begin{array}{l}\text { Peak age } \\
\text { of disease } \\
\text { onset } \\
\text { (years) }\end{array}$ & $\begin{array}{l}\text { Family } \\
\text { history \% }\end{array}$ & $\begin{array}{l}\text { Nail } \\
\text { involvement } \\
\%\end{array}$ & $\begin{array}{l}\text { Flexural } \\
\text { lesions } \\
\%\end{array}$ & $\begin{array}{l}\text { Oral } \\
\text { mucosal } \\
\text { lesions } \\
\%\end{array}$ & $\begin{array}{l}\text { Systemic } \\
\text { treatment (oral } \\
\text { retinoid) } \% \\
\text { Success rate, } \%\end{array}$ \\
\hline $\begin{array}{l}\text { Burge and } \\
\text { Wilkinson 1992 }\end{array}$ & Not specified & 163 & $11-91$ & $11-15$ & 71 & 90 & 6 & $13 \%$ & 61 \\
\hline Goh et al. ${ }^{6}, 2004$ & $1982-2002$ & 24 & $18-53$ & $11-20$ & 21 & 50 & 13 & $8 \%$ & 38 \\
\hline $\begin{array}{l}\text { Zeglaoui et al. }{ }^{\prime}, \\
\text { 2004 }\end{array}$ & $1971-2002$ & 12 & $8-39$ & $12-20$ & 42 & 58 & 16 & 0 & 50 \\
\hline Current study & $2008-2016$ & 9 & $11-67$ & $12-22$ & 22 & 56 & 33 & $11 \%$ & 55 \\
\hline
\end{tabular}




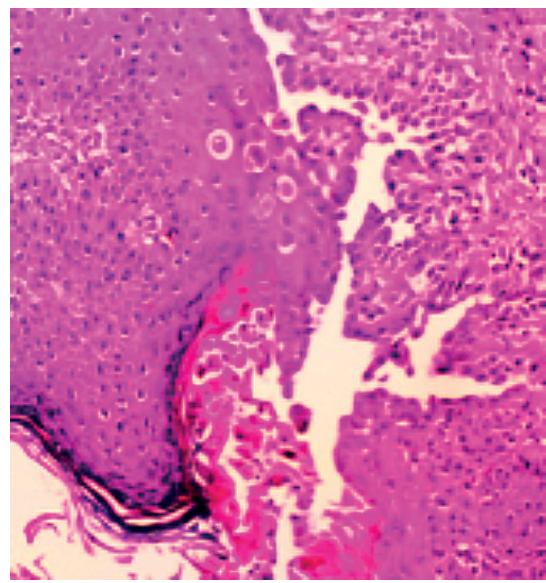

Figure 7. A group of dyskeratotic cells: Corps ronds with a pyknotic nucleus surrounded by a clear halo centrally located in the epidermis and grains with an elongated nucleus in the stratum corneum (hematoxylin\&eosin x200)

\section{Discussion}

Darier's disease is a rare autosomal dominant inherited disease that involves skin, nails and mucous membranes. It has been reported that both genders are equally affected, and the prevalence varies between $1 / 36.000$ and $1 / 100.000^{2,3}$. The current study confirms the rarity of Darier's disease with only 9 patients having been diagnosed in our outpatient clinic over the 8-year study period. In previous studies, Goh et al. ${ }^{6}$ diagnosed 24 patients over 20 years, and Zeglaoui et al. ${ }^{7}$ reported 12 cases over 31 years (Table 2).

A mutation in the ATP2A gene encoding the sarcoplasmic/endoplasmic reticulum calcium ATPase 2 has been found in the molecular basis of Darier's disease. The mutation at this locus results in the inhibition of the sarcoplasmic/endoplasmic reticulum pump, and the subsequent changes in calcium signaling cause abnormal keratinocyte differentiation. This leads to the loss of the epidermal connection caused by acantholytic and dyskeratotic cells, such as corps ronds and grains, which are characteristic of Darier's disease . $^{\text {. }}$

Although Darier's disease is inherited in an autosomal dominant pattern, non-familial cases are seen due to spontaneous mutation or incomplete penetrance ${ }^{9}$. The presence of family history was reported as $71 \%$ in the study by Burge and Wilkinson ${ }^{1}$ and $42 \%$ by Zeglaoui et al. ${ }^{7}$ In the current study, $22 \%$ of patients had a family history (Table 2). Skin findings usually start at the first or second decade of life and peak at puberty ${ }^{10}$. Sweating, sebum excretion, or changes in bacterial flora may lead to an increase in disease activity during puberty. In this study, the age of onset of the disease ranged from 8 to 47 years with the mean being 19.5. In all patients except 1, the disease started under the age of 24 . The latest onset was seen at age 47.

The first lesions occur primarily on seborrheic areas, such as scalp, nasolabial and retroauricular folds, chest and back. Initial lesions are small, hard, skin-colored papules. Later, the papules are covered by dark-black greasy crusts. Over time, the lesions unite to form plaques and vegetating masses, creating a thick and dirty appearance. The lesions in the deep folds of the skin are macerated, malodorous, and often secondarily infected ${ }^{11,12}$. It has been reported that papules similar to verruca plana on the back of hands and feet, and punctate keratoses and small pits in the palmoplantar area can be seen, and the grouped papular lesions may cause thickening of the cornified layer of the skin. In the nails, thinning, fragility, subungual keratosis and redwhite longitudinal lines can be present, as well as typical V-shaped splitting and longitudinal fissures on the distal part. Approximately $15 \%$ of patients have mucosal lesions in the form of white papules with a central depression (cobblestone appearance) ${ }^{7,10-12}$. Burge and Wilkinson ${ }^{1}$ reported acral lesions in $96 \%$ of patients, nail involvement in $90 \%$, flexural hypertrophic lesions in $6 \%$, and oral mucosa lesions in $13 \%$. In a study by Zeglaoui et al. ${ }^{7}, 58 \%$ of patients had nail dystrophy and $16 \%$ had flexible lesions with oral mucosal involvement not being detected in any of the patients. In the current study, $56 \%$ of patients had extremity involvement, 56\% nail involvement, 33\% flexible lesions and $11 \%$ oral mucosa lesions (Table 2). Usually, $80 \%$ of patients with Darier's disease have itching, which sometimes becomes unbearable ${ }^{13}$. In this study, $78 \%$ of patients had complaints of itching.

Localized, unilateral, zosteriform, acral, segmental, and flexural variants of Darier's disease have been defined ${ }^{1,14}$. Approximately $10 \%$ of patients with Darier's disease have the segmental form ${ }^{15}$. In this study, the findings in 1 patient were consistent with segmental Darier's disease, and in another patient, there were predominantly flexural lesions. Goh et al. ${ }^{6}$ reported three cases of flexural Darier's disease in a series of 24 patients.

Darier's disease is frequently accompanied by psychoneurological conditions, including mental retardation, epilepsy, psychosis, and manic depression ${ }^{7}$. Mental retardation was present in 1 of our patients.

Both dyskeratosis and acantholysis are seen in the pathology of Darier's disease. Achantolysis results in suprabasal cleft formation. Corps ronds are dyskeratotic cells in the stratum spinosum and stratum granulosum. They have a pyknotic nucleus and eosinophilic cytoplasm covered by a clear perinuclear halo. Grains are oval cells containing keratohyalin granules and are localized in the stratum corneum ${ }^{12}$. The histopathological features of our cases supported the diagnosis of Darier's disease.

Since Darier's disease is exacerbated by hot and humid environments, avoiding heat and using sun cream particularly during summer prevent aggravation of the condition ${ }^{7}$. In milder forms, moisturizers (especially those containing urea or lactic acid) reduce squamation and irritation, sun protection products, and topical corticosteroids can be used. Despite not being able to stop the progression of the rash, topical corticosteroids help relieve itching and can be used in combination with retinoids to reduce irritation. Classical topical retinoids and other topical retinoids with few side effects, such as tazarotene and adapalene are effective in controlling the localized form of the disease ${ }^{12,16,17}$. The most effective treatment for the common and serious forms is oral retinoids (acitretin, isotretinoin, and etretinate), which have a good clinical response $(90 \%)^{7}$.

In this study, topical retinoid and steroid therapy was administered to $44 \%$ of the patients with the mild/moderate or localized form of the disease. The complaints of the patients regressed with treatment, but recurrence was observed when the treatment was terminated. Oral retinoids were given to $56 \%$ of the patients, of whom $80 \%$ responded well. The rate of response to oral retinoid treatment was similar to that reported by other studies (Table 2)1,6,7.

\section{Study Limitation}

The single-centered and retrospective execution of this study constitutes a limitation of our study. 


\section{Conclusion}

We presented this case series to report on Darier's disease as a rare condition encountered in the differential diagnosis of dermatosis with keratotic papular lesions and emphasize its clinical diversity.

\section{Ethics}

Ethics Committee Approval: Because of the retrospective design, ethics committee approval was not needed.

Informed Consent: Informed consent form was obtained from all the patients included in this study.

Peer-review: External and internal peer-reviewed.

\section{Authorship Contributions}

Surgical and Medical Practices: S.S., E.S., M.S.G., Concept: S.S., A.E.K.A., M.S.G., Design: S.S., A.E.K.A., M.S.G., Data Collection or Processing: S.S., M.S.G., Analysis or Interpretation: S.S., A.E.K.A., M.S.G., C.L., Literature Search: S.S., Writing: S.S.

Conflict of Interest: No conflict of interest was declared by the authors.

Financial Disclosure: The authors declared that this study received no financial support.

\section{References}

1. Burge SM, Wilkinson JD: Darier-White disease: a review of the clinical features in 163 patients. J Am Acad Dermatol 1992;27:40-50.

2. Svendsen IB, Albrectsen B: The prevalence of dyskeratosis follicularis (Darier's disease) in Denmark: an investigation of the heredity in 22 families. Acta Derm Venereol 1959;39:256-69.
3. Munro CS: The phenotype of Darier's disease: penetrance and expressivity in adults and children. Br J Dermatol 1992;127:126-30.

4. Wilkinson JD, Marsden RA, Dawber RPR: Review of Darier's disease in the Oxford region. Br J Dermatol 1977:97:15-6.

5. Engin B, Kutlubay Z, Erkan E, Tüzün Y: Darier disease: A fold (intertriginous) dermatosis. Clin Dermatol 2015:33:448-51.

6. Goh BK, Ang P, Goh CL: Darier's disease in Singapore. Br J Dermatol 2005:152:284-8.

7. Zeglaoui F, Zaraa I, Fazaa B, et al: Dyskeratosis follicularis disease: case reports and review of the literature. J Eur Acad Dermatol Venereol 2005:19:114-7.

8. Szigeti R, Kellermayer R: Autosomal-dominant calcium ATPase disorders. $J$ Invest Dermatol 2006;126:2370-6.

9. Hakuno M, Akiyama M, Shimizu H, Wheelock MJ, Nishikawa T: Upregulation of P-cadherin expression in the lesional skin of pemphigus, Hailey-Hailey disease and Darier's disease. J Cutan Pathol 2001;28:277-81.

10. Sehgal VN, Srivastava G: Darier's (Darier-White) disease/keratosis follicularis. Int J Dermatol 2005;44:184-92.

11. Pişkin S, Özyılmaz F, Akgün N, Durukan N: Darier Hastalığı. Turkiye Klinikleri J Dermatol 2000;10:206-8.

12. Burge S, Hovnanian A: Acantholytic Disorders of the Skin. Fitzpatrick's Dermatology in General Medicine. Ed. Goldsmith LA, Katz SI, Gilchrest BA, Paller AS, Leffell DJ, Wolff K. 8'inci Baskı. The McGraw-Hill Companies 2012;550-6.

13. Hulatt L, Burge S: Darier's disease: hopes and challenges. J R Soc Med 2003;96:439-41.

14. Wada T, Shirakata $Y$, Takahashi $H$, et al: A Japanese case of segmental Darier's disease caused by mosaicism for the ATP2A2 mutation. Br J Dermatol 2003;149:185-8.

15. Tous Romero F, Burillo Martinez S, Raya-Morales C, Gargallo-Moneva V Maronas-Jimenez L: Segmental lesions along blaschko $\mathrm{S}$ lines in an elderly man. Dermatol Online J 2016;22.

16. Casals M, Campoy A, Aspiolea F, Carrasco MA, Camps A: Successful treatment of linear Darier's disease with topical adapalene. J Eur Acad Dermatol Venereol 2009;23:237-8.

17. Burkhart CG, Burkhart CN: Tazarotene gel for Darier's disease. J Am Acad Dermatol 1998;38:1001-2. 